\title{
Self-efficacy and School Leaders' Feedback: A Study of Iranian EFL Teachers
}

\author{
Tayebeh Mohammadzadeh \\ Department of English, Torbat-e-Heydarieh Branch, Islamic Azad University, Iran \\ E-mail: Tayebeh.mohammadzadeh90@yahoo.com \\ Khalil Motallebzadeh \\ Department of English, Torbat-e-Heydarieh Branch, Islamic Azad University, Iran \\ E-mail: k.motalleb@iautorbat.ac.ir; kmotallebz@gmail.com \\ Hamid Ashraf \\ Department of English, Torbat-e-Heydarieh Branch, Islamic Azad University, Iran \\ E-mail: h.ashraf@iautorbat.ac.ir; Hamid.ashraf.elt@gmail.com
}

\begin{abstract}
Received: October 20, 2013 Accepted: November 5, 2013 Published: November 5, 2013
doi:10.5296/ijele.v2i1.4511 URL: http://dx.doi.org/10.5296/ijele.v2i1.4511
\end{abstract}

\begin{abstract}
Many studies have described aspects of gender which might affect teachers' beliefs and attitudes toward their job and the quality of teachers' performance within the classroom seems to be highly influenced by different factors in and out of the classroom. This study sets out to investigate the effect of received feedback from school leaders on sense of efficacy of male and female EFL teachers. DeNisi and Kluger (2000) stated that feedback to ones' performance is an important element of having high job satisfaction and motivation. Considering the impression that teachers could not teach at advance levels, unless school leaders find them qualified enough for teaching at these levels, this study examines the effect of teachers' position in a language institute, regarding the levels they teach, on their perceived efficacy after receiving feedback. For this purpose, 30 male and female teachers who all teach at the same language school in Mashhad, a city in Iran, were selected. The participants were divided according to the level they taught, 15 at elementary levels and 15 at advance. The obtained data were analyzed through SPSS software (version 16). The numerical results proved teachers' sense of efficacy was influenced significantly by school leader's feedback and the change was positive. Also, sense of efficacy of teacher who taught at both elementary and advance levels increased but not significantly.
\end{abstract}

Keywords: Feedback, Self efficacy 


\section{Introduction}

Due to being a teacher and consequently having dealt with different school leaders, the researcher finds it of worth to investigate whether the feedback school leaders give to their teachers boost their motivation or ruin their intentions for betterment. Besides, due to all the differences between males and females it could be concluded that how they perceive feedback differs, too.

DeNisi and Kluger (2000) further provided that majority of decisions made by teachers and the models they follow in order to develop in their jobs are related to the feedback they receive on their performance. Therefore, for teachers being regarded as capable enough to teach at high levels is supposedly influenced by school leaders' idea on them and receiving feedback is a proper requirement for better performance by teachers. In other words, there is interaction between expectations of the school leaders and monitoring to obtain collaboration between them in one way and between teachers themselves in another way.

Knippen (1996) has stated that giving feedback has some advantages such as meeting what school leaders expect in the best way and improved performance; besides the need to meet the boss because of problems, questions or decisions becomes less frequent; and employees get more satisfactions.

Results of other studies have revealed that a key to accomplishment in teaching is the teacher's capability to manage the classroom and to establish education (Brophy, 1988; Cakmak, 2008; Emmer, Evertson, \& Worsham, 2000). Class management along with having appropriate knowledge to teach at high levels address the issue of the extent of impact of school leaders' feedback, whether constructive or destructive, on female and male teachers. Hence, it needs to be discovered whether teaching at high or low levels has anything to do with teachers' sense of efficacy and whether teachers who teach at these two levels take the comments of school leaders equally.

To address the above mentioned problem, the researcher addresses the following questions:

1) Do school leaders' feedbacks have the same effect on male and female teachers' level of self-efficacy?

2) Can school leaders' feedback affect self-efficacy of teachers at different position in the school similarly?

\section{Review of Literature}

The researcher aims to find the effect of school leaders' feedback on EFL teachers' sense of self-efficacy and consequently teachers' motivation and enthusiasm for effective performance. Within a school, the school leader is the one who has the responsibility of providing a caring and effective atmosphere (Hoy \& Tarter, 1992). Particularly, "supportive principals respect the competence of their faculty and exhibit both a personal and a professional interest in the well-being of their teachers" (Hoy et al., 1992, p. 38). By supportive and caring workplace, the need for encouragement, positive feedback and a "healthy" school atmosphere is meant. 
Fullan (2001) mentions that effective and attentive school leaders are the ones who listen considerately. Effective school leaders attempt to make the school environments a place to develop teachers and learners' success. Uline, Miller \& Tschannen-Moran (1998) claim, "teaching and learning takes place at the classroom level, whereas other levels of the organization are providing the conditions necessary for these activities to take place" (p. 463).

\subsection{School Leader}

In the 1930s, leadership was defined by the leader attribute theory which aimed to clarify normal traits of the leader which results in effective leadership. Natural characteristic assumed to result in position of leadership for individuals were having outstanding brainpower, good memory, and infinite energy along with being convincing. However, since it was not possible to make definite connection between leadership traits and leaders' acts, this theory did not last long among its supporters (Steers, Porter \& Bigley, 1996).

In the 1940s and 1950s, the dominant idea was around leader behavior theories. According to a research done by Ohio State University, there are two types of leadership: the first one is called primarily attention. In case of a school, it could be defined as the degree to which school leaders explain and elaborate responsibilities of the teachers. The second type of leadership is actually the one which includes constructive behaviors such as mutual trust, excellent rapport, and admiration between school leaders and teachers (Fleishman, Harris \& Burtt, 1955).

At the turn of the twentieth century, Hallinger, Bickman and Davis (1996) stated that principal leadership "can have an indirect effect on school effectiveness through actions that shape the school's learning climate" (p. 527). However, according to many researches, principal leadership is affected by individual and circumstantial strands, and types of leadership are different for various situations and depending on the situation, a specific type of leadership which is taught to be the most effective one would be manipulated (Hallinger et. al, 1996).

It could be said that the idea of the role of school leaders within the schools or institutes and the way they influence teachers has been of much concern among researchers. Edmonds (1979) believes that there might be some bad schools which are known to have good leaders, but no school is known to be good unless it has a good leader. According to him, school leaders have the most influential and essential role in the school's achievements.

It seems trust is a necessity for administrative support and has influential figure in teachers' performance. Having done a research through 44 primary schools in east of the United Sates, Hoy, Tarter, and Witkoskie (1992) identified role of organizational support significant for effectiveness of school. In other words, support and admiration of the school leaders or school leaders result in having teachers with higher level of self-efficacy. Therefore, teachers are more motivated and interested in developing their performance and more determined to solve their issues within the school environment and lack of support from school leaders lowers their sense of self-efficacy and self-assurance (Lortie, 1975).

As Bandura states, one's views on ability to perform actions to attain the intended result 
defines the degree of the impact (Bandura, 1977, 1986, 1997). The researcher believes that the notion of being talented in a profession is the result of one's belief about ability of performing an action which may lead in success. Consequently, teachers show more motivation and interest in improving their performance and try to solve their problems with much more determination and deficiency in providing support from the management hinders teachers' sense of self-efficacy and self-confidence (Lortie, 1975).

\subsection{Self-efficacy}

As cited in Gürol \& AktÕ (2010), the higher the teaching efficacy of a teacher, the greater the students' interest in school and learning materials (Tschannen- Moran et al, 1998). There is this idea that what a teacher thinks about his/her ability could be referred to as teacher's self-efficacy, so that it is possible for a teacher to gain valuable outcomes through engaging students even those who are not motivated enough for learning (Bandura, 1977; TschannenMoran, Woolfolk Hoy, \& Hoy, 1998).

It seems as if teacher's sense of efficacy is related to personalities and traits of students such as their enthusiasm, accomplishment, and effectiveness (Tschannen-Moran et al., 1998). Teacher efficacy is explained as "the teacher's belief in his or her capability to organize and execute courses of action required to successfully accomplish a specific teaching task in a particular context” (Tschannen-Moran et al., 1998, p. 22).

Generally, it could be concluded that teacher's sense of efficacy is the most influential reason of teacher's improvement and betterment. Besides, it is believed that teacher who have higher level of self-efficacy are more eager to their job (Allinder, 1994; Guskey, 1984), more dedicated (Coladarci, 1992; Evans \& Tribble, 1986; Trentham, Silvern, \& Brogdon, 1985), and less likely to leave teaching (Glickman \& Tamashiro, 1982).

As cited in Cerit, 2010, one of the important beliefs considered to be significantly effective in students and teachers outcomes is teachers' feelings of efficacy (Chaco'n, 2005). Therefore, as schools improve, teachers with high level of self-efficacy have more tendency to accept new thoughts and more enthusiastic to try and accept teaching improvements in order to find better solutions to students' needs (Allinder, 1994; Ghaith \& Yaghi, 1997; Guskey, 1984, 1988; Smylie, 1988; Stein \& Wang, 1988), to apply more practical methods of teaching (Riggs \& Enochs, 1990), to practice less teacher-oriented instructions for whole class (Ashton $\&$ Webb, 1986), and to approve of humanistic classroom directing (Woolfolk, Rosoff, \& Hoy, 1990).

Brookoveret. al. (1978) worked on social-psychological variables which could set common socioeconomic standards for schools based on students' educational acts. The findings revealed that teachers who had more contributions to students and reinforced them positively had more achievement-seeking students (Brookover et. al, 1978).In conclusion, teachers of high sense of efficacy are more reliable, self-assured and enthusiastic and their classes are much more successful. They behave friendly and pleasantly to students. 


\subsection{Causes of Efficacy}

According to Bandura (1977) there are four bases for efficacy: act achievements; experiences of other individuals; oral encouragements; and, emotional stimulations. Due to direct involvement of the individual in completing a task to achieve accomplishments, it could be claimed that act achievements have the most influential effects on increasing self- efficacy beliefs. Also, when individuals notice similarity between performances of successful people and their own acts, they feel more confident and efficient.

According to many researches in the area, teachers' feeling of self-efficacy is closely joined with instructional success and school improvements (Armor et al., 1985; Ashton \& Webb, 1986; Berman \& McLaughlin, 1977; Dembo \& Gibson, 1985; Hoy \& Woolfolk, 1993; McLaughlin \& Marsh, 1978; Tschannen-Moran et al., 1998). Therefore, many researchers share the idea of the existence of a direct relation between students' improvement and highly efficient teachers (Tracz \& Gibson, 1986). More precisely, according to the studies in the area it is concluded that both school management (Leithwood, 1977) and teachers' proficiency and improvement (McLaughlin \& Berman, 1977; Scribner, 1998) have influence on the level of teacher's self-efficacy, and as a consequence on students' success and development; the purpose of this section is reviewing the literature related to these two strands and their effect on teacher's self-efficacy.

Lortie in a study done in 1975 recommends that management that does not support the school and provides teachers with not very positive feedback impacts their self-confidence. Bandura (1977) gave emphasis on the significance of feedback and evaluations in influencing teachers' feeling of collective efficacy. Pajares (2002) also indicates that there is a link between collective efficacy and teachers' self-efficacy and school management approval, as well.

Therefore, the researcher finds it of worth to review the role of school leaders and /or school leaders on sense of self-efficacy among teachers. However, receiving constructive or destructive feedback is not the focus of the researcher but the focus is on evaluating the way feedback is given to teachers.

\subsection{Feedback}

There have been researches which investigated variables that have impact on workers' intentions to follow feedback (e.g., Ashford 1986). And some researches have studied how employees' choices to follow feedback are influenced by characteristics of the source of feedback, (Morrison\& Vancouver 1993), their rational processes in organizing and making use of feedback (cf. Atwater \& Yammarino 1995), and issues affecting raters' truthfulness and incentive (cf. Ilgen, Barnes-Farrell, \& McKellin 1993). Along with these studies, some found it necessary to search in the area of issues affect motivation of a school leaders for giving feedback.

Harris (1994) studied contextual and individual features which could advance motivation of the feedback giver. According to him, contextual aspects could be ones like raters' criticizing position which result if feeling of surrender. Individual aspects include the extent of available 
information of the feedback source and his/her level of self-efficacy and attitude. Harris stated that there has been not much work on motivation for giving feedback expect for work by Larson $(1984,1986,1989)$.

Comparing a motivated rater with a non-motivated, Harris assumed that the former has more tendencies to offer appropriate, truthful, and precise feedback. However, it seems that merely the findings that claim raters are unwilling to give feedback (Benedict \& Levine 1988), misrepresent feedback (Larson 1989), and provide little precision (Larson 1986) could support this hypothesis.

\section{Methodology}

\subsection{Participants}

In order to gather the required data for this study, the researcher asked 50 EFL teachers to answer a questionnaire on self-efficacy. All the participants were male and female teachers in an English Institute in Mashhad, a city in Northeast of Iran. The participants aged between 25- 55. Teachers held either bachelors or master's degree but not all in English. Some of them taught at elementary and some at advance levels. Due to lack of time, merely thirty of teachers were observed by the school leader and received his comments, though randomly and only they were requested to answer the same questionnaire once again.

\subsection{Instruments}

The questionnaire used in this research was a researcher-made one which was used for two times, once at the beginning of the term and once at the end of the term. The applied questionnaire was made based on Tschannen-Moran \& Woolfolk-Hoy's self-efficacy questionnaire (2001), Bandura's Teacher Self-efficacy Scale (1997), and Murdoch's Good Teacher's questionnaire (1997). However, the inventory was localized based on the Iranian EFL teachers' specifications. The questionnaire contained 30 items which were grouped within five subscales: (1) efficacy to influence decision-making -2 items (2) instructional efficacy-15 items, and (3) disciplinary efficacy-2 items, (4) efficacy to enlist parental and community involvement -3 items (5) efficacy to create a positive school climate- 8 items. The reliability of the questionnaire was calculated by Cronbach's alpha which was 0.90 and the participants were expected to only mark the questions. To ensure validity of the questionnaire, two experts in the area, checked it for several times.

According to their suggestions, in order to tap maximum efficacy of respondents, repeatedly some items were discarded and some others were added. Also, since the questionnaire was to show respondents' judgments on their capabilities, the term can was used in all the items.

\subsection{Procedure}

In this study, the researcher aimed to discover whether teachers were affected by feedback received from their school leader. Besides, it was decided to select participants who taught at elementary level in order to be compared with the ones who teach at advance levels. Hence, it could be possible for the researcher to estimate the level of efficacy of teachers of both levels and to examine the degree each of which is influenced by school leader's feedback. 


\section{MlMacrothink}

The required data for this study was gathered from teachers through a questionnaire which contained30 Liker-scale questions to which participants were required to indicate their opinions. At the end of term when the school leader observed at least 30 of teachers, the required number of participants for the study, they were asked to answer the same questionnaire once again. However, due to limitation of having more teachers being observed by the school leader, the researcher deliberately excluded teachers who taught at intermediate levels from the research. Having received feedback, 30 of the observed teachers were requested to fill in the previous questionnaire which was on self-efficacy, so that the researcher could discover whether the school leaders' comments had any effect on teachers' feeling of self-efficacy. All the comments of the school leader fell in the same fields for all teachers. They received feedback in one or two days after being observed. The number of teachers in each group was 15 . The whole process of exploring the level of teachers' self -efficacy and the degree to which it was affected by school leaders' feedback which was the ultimate goal of this study lasted around 3 months because there were some intervals between observations. However, the estimated time required for answering the questionnaire for each participant was less than 10 minutes.

\section{Results}

A paired-sample t-test was conducted to calculate the impact of the feedback on teachers' self-efficacy. As it is shown in Table 1, there is a positive significant effect of school leader's feedback on teachers' sense of self-efficacy $(\operatorname{sig}<0.05)$.

Table 1. General Effect of Feedback on Self-Efficacy

\begin{tabular}{|c|c|c|c|c|c|c|c|c|c|}
\hline & & \multicolumn{5}{|c|}{ Paired Differences } & \multirow{3}{*}{ 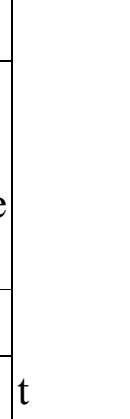 } & \multirow[b]{3}{*}{ df } & \multirow{3}{*}{$\begin{array}{l}\text { Sig. } \\
\text { (2-tailed) }\end{array}$} \\
\hline & & \multirow[b]{2}{*}{ Mean } & \multirow{2}{*}{$\begin{array}{l}\text { Std. } \\
\text { Deviation }\end{array}$} & \multirow{2}{*}{$\begin{array}{l}\text { Std. Error } \\
\text { Mean }\end{array}$} & \multicolumn{2}{|c|}{$\begin{array}{l}95 \% \\
\text { Confidence } \\
\text { Interval of the } \\
\text { Difference }\end{array}$} & & & \\
\hline & & & & & Lower & Upper & & & \\
\hline Pair 1 & $\begin{array}{l}\text { Total } \\
\text { Self-Efficacy } \\
\text { TSE2 }\end{array}$ & -5.400 & 12.912 & 2.357 & -10.222 & -.578 & -2.291 & 29 & .029 \\
\hline
\end{tabular}

There was a statistically significant increase in self-efficacy of teachers from Time 1 which was before receiving feedback $(\mathrm{M}=103.87, \mathrm{SD}=15.909)$ to Time 2 which is after receiving feedback $(\mathrm{M}=109.27, \mathrm{SD}=21.089), \mathrm{t}(29)=-2.291, \mathrm{p}<.05$ ( two-tailed). The mean increase in self-efficacy was-5.4with a 95\% confidence interval ranging from -10.222 to -.578 . 
Table 2. Taught Level at school

\begin{tabular}{|c|c|c|c|c|c|c|}
\hline Level being & taught & & Mean & $\mathrm{N}$ & $\begin{array}{l}\text { Std. } \\
\text { Deviation }\end{array}$ & Std. Error Mean \\
\hline Elementary & Pair 1 & $\begin{array}{l}\text { Total } \\
\text { Self-Efficacy } \\
\text { TSE2 }\end{array}$ & $\begin{array}{l}102.06 \\
103.41\end{array}$ & $\begin{array}{l}15 \\
15\end{array}$ & $\begin{array}{l}17.358 \\
23.332\end{array}$ & $\begin{array}{l}4.210 \\
5.659\end{array}$ \\
\hline Advance & Pair 1 & $\begin{array}{l}\text { Total } \\
\text { Self-Efficacy } \\
\text { TSE2 }\end{array}$ & $\begin{array}{l}106.23 \\
116.92\end{array}$ & $\begin{array}{l}15 \\
15\end{array}$ & $\begin{array}{l}14.114 \\
15.392\end{array}$ & $\begin{array}{l}3.914 \\
4.269\end{array}$ \\
\hline
\end{tabular}

According to Table 2, generally the upper the level being taught by teachers, the higher sense of efficacy teachers had. Also, the table shows that efficacy of teachers in both groups had been increased after receiving feedback from the school leader, however it was not significant. Therefore, it seems as if teaching at high levels makes teachers feel more efficient.

To sum up, it seemed as if feedback had significant effect on teachers' sense of efficacy. As cited in Yang, 2011, in the area of English teaching, there has not been considerable attention to teachers, while teachers, apart from the methods and resources they might use, have significant role in improvement of English language teaching (Freeman, 1991).

The results also implied the fact that school leaders have noticeable role in the process of education. However, factors such as teachers' personal characteristics and the level they teach could reduce or enhance this influence. And there seemed more emphasis was required to the role of both teachers and school leaders.

\section{Discussion}

The purpose of this research was to investigate the effect of school leader's feedback on EFL teachers in an English school. The whole process of observing teachers by school leader and providing them with feedback took a semester. The results analyzed by SPSS software (version 16) proved a significant effect of feedback on sense of efficacy among teachers.

The idea that teachers are influenced by school leader's feedback is presented in a study by Tschannen-Moran and Hoy (2007):

Vicarious experiences are those in which the target activity is modeled by someone else. The impact of the modeled performance on the observer's efficacy beliefs depends on the degree to which the observer identifies with the model. When a model with whom the observer closely identifies performs well, the self-efficacy of the observer is enhanced. When the model differs, for example in terms of the level of experience, training, gender, or race, then even witnessing a very competent performance may not enhance the self-efficacy beliefs of the observer.(p. 945)

The present study aimed to find the effect of school leader's comments on sense of efficacy 
of Iranian EFL teachers working in English schools. According to the obtained data of the current study, teachers are influenced by school leader's feedback. As in a study on feedback, Pekkanli (2011) stated:

Communication and the quality of the feedback are important factors because the ways they are presented can determine its acceptance by the teacher candidate. It is claimed that "when school leaders deliver critical feedback to subordinates, it is hoped that the recipients will focus on the content of the message to gain information about ways of improving job performance. (p. 1157)

It seemed as if teachers prefer being observed by the school leader and receiving his comments, even though they might be negative and destructive, to being ignored by him. In other words, as long as teachers are respected by supervisor, they take even his critical comments. Hence, it could be concluded that to avoid any offensive and disrespectful comments, school leader would better to give their comments through indirect ways such as meetings with all teachers or announcing ideas through memorandums on bulletin board.

Besides, comparing teachers who teach at high levels with the ones who teach at elementary levels, the results of this study vindicated that the teachers of the former group were more efficient and their sense of efficacy increased after receiving feedback from the school leader. However, teachers of the latter group gained higher sense of efficacy after being provided by school leader's feedback. Therefore, results lead on to believe that successful teachers are the ones who have got the opportunity of teaching at high levels. However, it should not be ignored that there are various reasons, at both teacher and school leader's side, for a teacher to be recognized as capable for teaching at advance levels.

To summarize, teachers are vulnerable to the school leader's feedback. However, there might be different aspects which could strengthen or lessen the effect of feedback provided by school leaders. All the findings of this research suggest a need for having a more cautious attention to the issues between school leaders and teachers of an English school and their collaboration might affect teachers' act and thus students' progress.

\section{Conclusion}

This research was conducted to examine the effect of school leader's feedback on teachers' sense of efficacy and explore whether the level teachers teach at has any effect of the degree teachers take school leader's comments. According to the results of the study, there is significant effect of school leader's feedback on self -efficacy of teachers. Also, the results of the study proved that level being taught by teacher could enhance or lower their sense of efficacy, by itself. Furthermore, receiving feedback on teachers' performance from an authority such as school leader influences teachers' feeling of efficacy.

Results of this study, in line with many other studies, suggest more attention to teachers' approval with the school context which ultimately affects their whole performance within the classroom. It seems necessary to conduct studies on teachers' perceived sense of efficacy in relation to their commitment toward their students and their job. Further studies are required to discover the effect of school leader's comments on teachers' motivation for betterment and 
improvement. The results of this research call for further studies on finding the effect of school leaders' indirect ways of giving feedback to teachers. Furthermore, it would be of value to attempt to find the possible effect of supervisor's university degree, age, gender on the way he or she provides feedback and the amount teachers take his/her comments and ideas.

Lastly, replication of the current study within other schools in other cities could be helpful for the pedagogical purposes.

\section{References}

Allinder, R. M. (1994). The relationship between efficacy and the instructional practices of special education teachers and consultants. Teacher Education and Special Education, 17, $86-95$.

Armor, D., Conroy-Osequera, P., Cox, M., King, N., McDonnell, L., Pascal, A., Pauly, E., \& Zellan, G. (1976). Analysis of the school preferred reading programs in selected Los Angeles minority schools (Report No. R-2007-LAUSD).

Ashton, P. T., \& Webb, R. B. (1986). Making a difference: Teachers'sense of efficacy and student achievement. New York: Longman.

Atwater, L. E., \& Yammarino, F. J. (1995). “Antecedents and Consequences of Self- Other Rating Agreement: A Review and Model." In Research in Personnel and Human Resources Management, edited by J. Ferris.

Bandura, A. (1977). Self-efficacy: Toward a unifying theory of behavioral change. Psychological Review, 84, 191-215.

Bandura, A. (1986). Social Foundations of Thought and Action: A Social Cognitive Theory (Englewood Cliffs, NJ: Prentice-Hall).

Bandura, A. (1997). Self-efficacy: The exercise of control. New York: W. H. Freeman and Company.

Benedict, M. E., \& Levine E. L. (1988). "Delay and Distortion: Tacit Influences on Performance Appraisal Effectiveness.” Journal of Applied Psychology, 73, 507- 514.

Berman, P., \& McLaughlin, M. W. (1977). Federal programs supporting educational change. Vol. VII: Factors affecting implementation and continuation (Report No. R-1589/7 HEW). Santa Monica, CA.: The RAND Corporation.

Brookover, W., Schweitzer, J., Schneider, J., Beady, C., Flood, P., \& Wisenbaker, J. (1978). Elementary school social climate and school achievement. American Educational Research Journal, 15, 301-318.

Brophy, J. (1988). Educating teachers about managing classrooms and students. Teaching and Teacher Education, 4(1), 1-18.

Cakmak, M. (2008). Concerns about teaching process: Student teacher's perspectives. 
Education Research Quarterly, 31(3), 57-77.

Chaco'n, C. T. (2005). Teachers' perceived efficacy among English as a foreign language teacher in middle schools in Venezuela. Teaching and Teacher Education, 21, 257-272.

Coladarci, T. (1992). Teachers' sense of efficacy and commitment to teaching. Journal of Experimental Education, 60, 323-337.

Dembo M. H., \& Gibson, S. (1985). Teachers' sense of efficacy: An important factor in school improvement. The Elementary School Journal, 86(2), 173-184.

DeNisi, A., \& Kluger, A. (2000). Feedback effectiveness: can 360-degree appraisals be improved? Academy of Management Executive, 14(1), 129-139. http://dx.doi.org/10.5465/AME.2000.2909845

Edmonds, Ronald R. (1979). "Some Schools Work and More Can." Social Policy, March/April, pp. 28-32.

Emmer, E. T., Evertson, C., \& Worsham, M. E. (2000). Classroom management for secondary teachers (5 th ed.). Allyn and Bacon, Boston.

Evans, E. D., \& Tribble, M. (1986). Perceived teaching problems, self-efficacy and commitment to teaching among preservice teachers. Journal of Educational Research, 80, $81-85$.

Fleishman, E. A., Harris, E. F., \& Burtt, H. E. (1955). Leadership and supervision in industry. Columbus: Ohio State University Bureau of Educational Research.

Freeman, D. (1991). To Make the Tacit Explicit: Teacher Education, Emerging Discourse, and the Conceptions of Teaching. Teaching and Teachers Education, 7(5/6), 439-454.

Fullan, M. (2001). Leading in a culture of change. San Francisco, CA: Jossey-Bass.

Ghaith, G., \& Yaghi, M. (1997). Relationships among experience, teacher efficacy and attitudes toward the implementation of instructional innovation. Teaching and Teacher Education, 13, 451-458.

Gibson, S., \& Dembo, M. (1984). Teacher efficacy: A construct validation. Journal of Educational Psychology, 76, 569-582.

Glickman, C., \& Tamashiro, R. (1982). A comparison of first-year, fifth-year, and former teachers on efficacy, ego development, and problem solving. Psychology in Schools, 19, $558-562$.

Guskey, T. R. (1984). The influence of change in instructional effectiveness upon the affective characteristics of teachers. American Educational Research Journal, 21, 245-259.

Hallinger, P., Bickman, L., \& Davis, K. (1996). School context, principal leadership, and students reading achievement. The Elementary School Journal, 95(5), 527-549.

Harris, M. M. (1994). "Rater Motivation in the Performance Appraisal Context: A Theoretical 
Framework." Journal of Management, 20, 737-756.

Hoy, W. K., \& Tarter, C. J. (1992). Measuring the health of the school climate: A conceptual framework. NASSP Bulletin, 76, 74-79.

Ilgen, D. R., Barnes-Farrell, J. L., \& McKellin, D. B. (1993). "Performance Appraisal Process Research in the 1980s: What has it Contributed to Appraisals in Use?" Organizational Behavior and Human Decision Processes, 54,321-368.

Knippen, J. T., \& T. B. Green, (1996). How to get feedback from your boss.Employee Counseling Today. The Journal of Workplace Learning, 8(5), 13-16. http://dx.doi.org/10.1108/13665629610127744

Larson, J. R., Jr, (1984). The Performance Feedback Process: A Preliminary Model. Organizational Behavior and Human Performance, 33, 42-76.

Larson, J. R., Jr. (1986). Supervisors' Performance Feedback to Subordinates: The Impact of Subordinate Performance Valence and Outcome Dependence. Organizational Behaviorand Human Performance, 37, 391-408.

Larson, J. R., Jr. (1988). The Dynamic Interplay between Employees' Feedback-Seeking Strategies and Supervisors' Delivery of Performance Feedback. Academy of Management Review, 14, 408-422.

Leithwood, K. (1997). The nature of leadership survey. Unpublished manuscript, The Ontario Institute Studies in Education: University of Toronto at Toronto, Canada.

Lortie, D. (1975). Schoolteacher: a sociological study, Chicago, IL, The University of Chicago Press.

McLaughlin, M., \& Berman, P. (1977). Retooling staff development in a period of retrenchment. Educational Leadership, 35(3), 191-194.

Morrison, E. W., \& J. B. Vancouver. (1993). The Effects of Source Attributes on Feedback Seeking. Presented at the Annual Meeting of the Academy of Management, Atlanta, GA.

Pajares, F. (2002). Self-efficacy beliefs in academic contexts: An outline. Retrieved October 31, 2003 from http://www.emory.edu/EDUCATION/mfp/efftalk.html

Pekkanli, I. (2011). Designing a Questionnaire Attempting to Discover Mentors ${ }^{\text {ee }}$ Feedback in the Professionalism of the Foreign Language Teacher Candidate. Journal of Language Teaching and Research, 2(3), 600-604.

Riggs, I., \& Enochs, L. (1990). Toward the development of an elementary teacher's science teaching efficacy belief instrument. Science Education, 74, 625-638.

Ross, J. A. (1995). Strategies for enhancing teachers' beliefs in their effectiveness: Research on a school improvement hypothesis. Teachers College Record, 97, 227-250.

Scribner, J. P. (1998, October). Teacher efficacy and teacher Professional learning: What school leaders should know. Paper presented at the Annual Convention of the University 


\section{Macrothink \\ International Journal of English Language Education \\ ISSN 2325-0887 \\ 2013, Vol. 2, No. 1}

Council for Educational Administration, St. Louis, MO.

Smylie, M. A. (1988). The enhancement function of staff development: Organizational and psychological antecedents to individual teacher change. American Educational Research Journal, 25, 1-30.

Steers, Richard M., Lyman W. Porter, \& Gregory A. (1996). Bigley. Motivation and Leadership at Work (6th ed.). New York: McGraw-Hill.

Stein, M. K., \& Wang, M. C. (1988). Teacher development and school improvement: The process of teacher change. Teaching and Teacher Education, 4, 171-187.

Tracz, S. M., \& Gibson, S. (1986, November). Effects of efficacy on academic achievement. Paper presented at the Annual Meeting of the California Educational Research Association.

Trentham, L., Silvern, S., \& Brogdon, R. (1985). Teacher efficacy and teacher competency ratings. Psychology in Schools, 22, 343-352. Special Education, 17, 86-95.

Tschannen-Moran, M., Woolfolk Hoy, A., \& Hoy, W. K. (1998). Teacher efficacy: Its meaning and measure. Review of Educational Research, 68, 202-248.

Tschannen-Moran, M., \& Woolfolk Hoy, A. (2001). Teacher efficacy: Capturing an elusive construct. Teaching and Teacher Education, 17, 783-805.

Uline, C., Miller, D., \& Tschannen-Moran, M. (1998). School effectiveness: The underlying dimensions. Educational Administration Quarterly, 34, 462-483.

Woolfolk, A. E., Rosoff, B., \& Hoy, W. K. (1990). Teachers' sense of efficacy and their beliefs about managing students. Teaching and Teacher Education, 6, 137-148.

Yang, J. (2011). Teacher Efficacy and College English Teaching. Asia-Pacific Science and Culture Journal, 1(1), 34-42). http://www.ieit-web.org/apscj

\section{Copyright Disclaimer}

Copyright reserved by the author(s).

This article is an open-access article distributed under the terms and conditions of the Creative Commons Attribution license (http://creativecommons.org/licenses/by/3.0/). 